\title{
Deferasirox effectively reduces iron overload in non-transfusion-dependent thalassemia (NTDT) patients: 1-year extension results from the THALASSA study
}

\author{
Ali T. Taher • John B. Porter • Vip Viprakasit • Antonis Kattamis • \\ Suporn Chuncharunee • Pranee Sutcharitchan • Noppadol Siritanaratkul • \\ Renzo Galanello • Zeynep Karakas • Tomasz Lawniczek • Dany Habr • \\ Jacqueline Ros • Zewen Zhu $\cdot$ M. Domenica Cappellini
}

Received: 28 March 2013 / Accepted: 25 May 2013 / Published online: 18 June 2013

(C) The Author(s) 2013. This article is published with open access at Springerlink.com

\begin{abstract}
Patients with non-transfusion-dependent thalassemia (NTDT) often develop iron overload that requires chelation to levels below the threshold associated with complications. This can take several years in patients with high iron burden, highlighting the value of long-term chelation data. Here, we report the 1-year extension of the THALASSA trial assessing deferasirox in NTDT; patients continued with deferasirox or crossed from placebo to deferasirox. Of 133 patients entering extension, 130 completed. Liver iron concentration (LIC) continued to decrease with deferasirox over
\end{abstract}

Trial registration: clinicaltrials.gov identifier: core study NCT00873041; extension study NCT01185106

Electronic supplementary material The online version of this article (doi:10.1007/s00277-013-1808-z) contains supplementary material, which is available to authorized users.

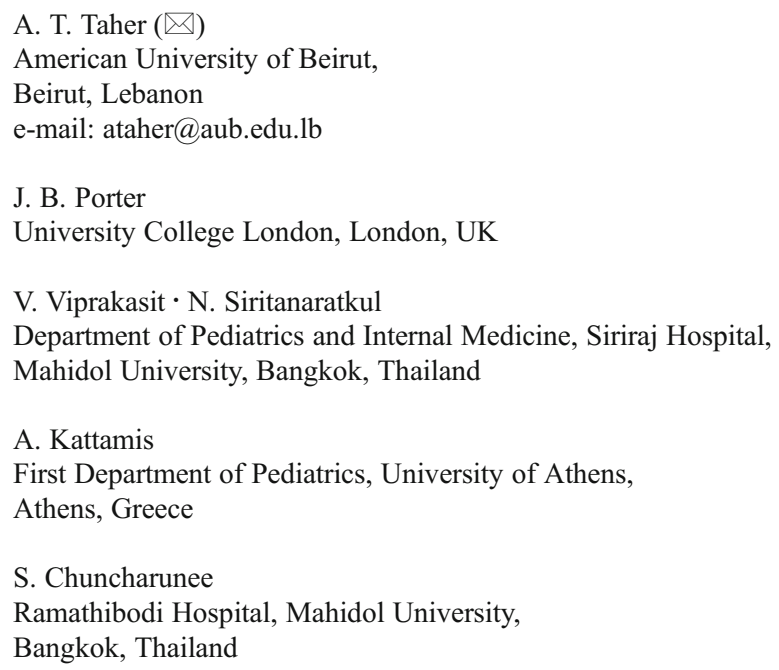

2 years; mean change was $-7.14 \mathrm{mg} \mathrm{Fe} / \mathrm{g}$ dry weight (dw) (mean dose $9.8 \pm 3.6 \mathrm{mg} / \mathrm{kg} /$ day). In patients originally randomized to placebo, whose LIC had increased by the end of the core study, LIC decreased in the extension with deferasirox with a mean change of $-6.66 \mathrm{mg} \mathrm{Fe} / \mathrm{g}$ dw (baseline to month 24; mean dose in extension $13.7 \pm 4.6 \mathrm{mg} / \mathrm{kg} /$ day). Of 166 patients enrolled, $64(38.6 \%)$ and 24 (14.5\%) patients achieved LIC $<5$ and $<3 \mathrm{mg} \mathrm{Fe} / \mathrm{g} \mathrm{dw}$ by the end of the study, respectively. Mean LIC reduction was greatest in patients with the highest pretreatment LIC. Deferasirox progressively

\author{
P. Sutcharitchan \\ Chulalongkorn University and King Chulalongkorn Memorial \\ Hospital, Bangkok, Thailand \\ R. Galanello \\ Ospedale Regionale Microcitemie, Dipartimento Scienze \\ Biomediche e Biotechnologie, Università di Cagliari, Cagliari, Italy \\ Z. Karakas \\ Istanbul Medical Faculty, Istanbul University, Istanbul, Turkey \\ T. Lawniczek $\cdot$ J. Ros \\ Novartis Pharma AG, Basel, Switzerland \\ D. Habr · Z. Zhu \\ Novartis Pharmaceuticals, East Hanover, NJ, USA \\ M. D. Cappellini \\ Ca Granda Foundation IRCCS, Università di Milano, Milan, Italy
}


decreases iron overload over 2 years in NTDT patients with both low and high LIC. Safety profile of deferasirox over 2 years was consistent with that in the core study.

Keywords Iron overload · Iron chelation · Non-transfusiondependent thalassemia $\cdot$ Deferasirox

\section{Introduction}

In patients with non-transfusion-dependent thalassemias (NTDT), such as beta-thalassemia intermedia, alpha-thalassemia (mainly $\mathrm{HbH}$ disease), and mild/moderate forms of $\mathrm{HbE} /$ beta-thalassemia, iron overload is an important challenge in terms of diagnosis, monitoring, and treatment. Increased intestinal absorption of iron, caused by ineffective erythropoiesis, is the main cause of iron overload in these patients, which can become clinically relevant by the age of 10 years [1]. Iron overload is associated with liver dysfunction and vascular, bone, and endocrine morbidities [2]. A wealth of information on iron overload and its management is available from transfusion-dependent betathalassemia major. However, given the differences in iron metabolism, pathophysiology, and iron loading rate in patients with NTDT, a direct extrapolation cannot be made, making it important to investigate iron overload in NTDT [3-11].

THALASSA (assessment of Exjade ${ }^{\circledR}$ in non-transfusiondependent THALASSemiA patients) is the first randomized, double-blind, placebo-controlled trial to assess deferasirox (Novartis Pharmaceuticals, East Hanover, NJ, USA) for investigational use in patients with NTDT [9]. Results from the 1-year THALASSA study, the largest dataset to date in NTDT patients, showed that liver iron concentration (LIC) significantly decreased versus placebo [least-squares mean $(\mathrm{LSM}) \pm$ standard error]: $-2.33 \pm 0.7(p=0.001)$ and $-4.18 \pm$ $0.69 \mathrm{mg} \mathrm{Fe} / \mathrm{g}$ dry weight $(\mathrm{dw})(p<0.001)$ for deferasirox starting doses of 5 and $10 \mathrm{mg} / \mathrm{kg} /$ day, respectively [9]. LIC increased by $0.38 \mathrm{mg} \mathrm{Fe} / \mathrm{g} \mathrm{dw}$ in patients receiving placebo [9]. Patients treated with deferasirox had a similar frequency of overall adverse events (AEs) as patients treated with placebo [9].

In order to provide longer-term deferasirox data in NTDT patients and to assess whether a greater number of patients could reach the therapeutic goal of LIC $<5$ and $<3 \mathrm{mg} \mathrm{Fe} / \mathrm{g}$ $\mathrm{dw}$ than observed in the core study, a 1-year extension phase was carried out. This allowed assessment of up to 2 years of deferasirox treatment, the longest assessment of chelation in a controlled trial in NTDT patients, and the opportunity for patients treated with placebo in the core to receive deferasirox in the extension phase, as well as to provide further guidance on dosing and monitoring strategies.

\section{Methods}

Study design

THALASSA is a multinational, prospective, randomized, double-blind, placebo-controlled phase II study (27 centers across nine countries). Study design/inclusion/exclusion criteria have been described previously [9].

Patients randomized to deferasirox during the core (starting dose 5 or $10 \mathrm{mg} / \mathrm{kg} /$ day) and those receiving placebo had the option to enter a pre-planned, 1-year, open-label extension phase. Written, informed consent was required prior to extension entry. Patients with continuous increases in serum creatinine $\geq 33 \%$ above baseline and above the upper limit of normal (ULN), alanine aminotransferase (ALT) $>2 \times$ baseline and $>5 \times$ ULN, or progressive proteinuria that did not improve after drug interruption/dose reduction in the core were excluded from entering the extension.

Deferasirox starting doses in the extension were based on LIC at the end of core and response to chelation (Fig. 1). Extension dosing therefore differed from the core; patients could start the extension receiving $20 \mathrm{mg} / \mathrm{kg} /$ day whereas in the core starting doses were randomly assigned as 5 or 10$\mathrm{mg} / \mathrm{kg} /$ day. After 6 months in the extension, dose adjustments were made based on LIC measurement [9]. Dose adjustment recommendations were also provided based on continuous safety assessments. Treatment was to be interrupted in patients reaching $\mathrm{LIC}<3 \mathrm{mg} \mathrm{Fe} / \mathrm{g} \mathrm{dw}$ or serum ferritin $<100 \mathrm{ng} / \mathrm{mL}$.

The study was conducted in accordance with Good Clinical Practice guidelines and the Declaration of Helsinki. The study

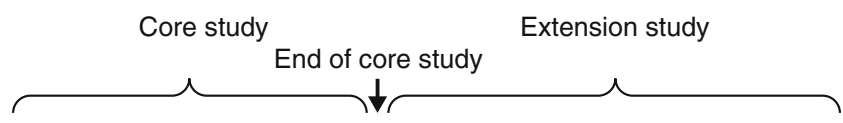

$$
\text { LIC (mg Fe/g dw) }
$$

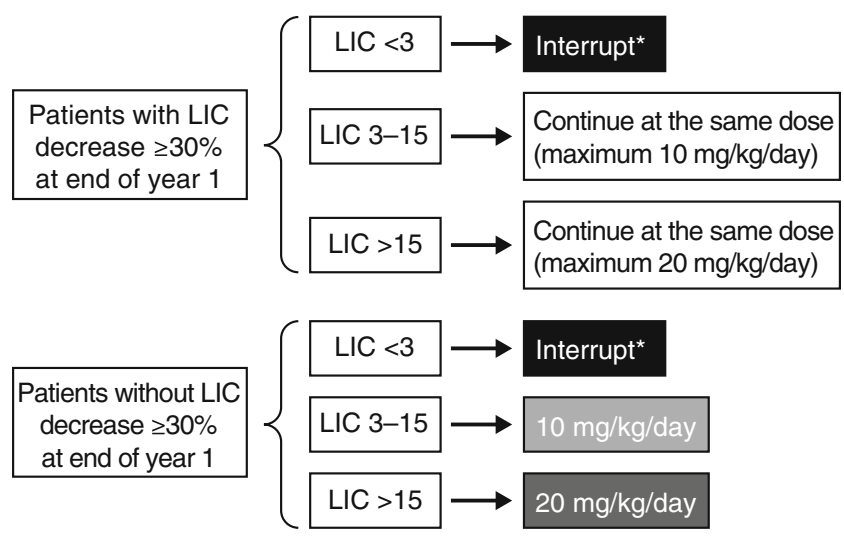

Fig. 1 Starting doses in the THALASSA extension study. *Wait until LIC $>5 \mathrm{mg} \mathrm{Fe} / \mathrm{g} \mathrm{dw}$ and then restart at $5 \mathrm{mg} / \mathrm{kg} /$ day if $5 \mathrm{mg} / \mathrm{kg} /$ day was effective before interruption or at $10 \mathrm{mg} / \mathrm{kg} /$ day if $10-20 \mathrm{mg} / \mathrm{kg} / \mathrm{day}$ was effective before interruption 
was approved by local ethics committees of study sites. An independent data monitoring committee reviewed safety data and advised on study continuation and/or protocol changes.

\section{Assessments}

The primary efficacy endpoint for the extension was the number and proportion of patients reaching LIC $<5 \mathrm{mg}$ $\mathrm{Fe} / \mathrm{g} \mathrm{dw}$ by the end of the extension. Additional analyses included assessment of the number and proportion of patients with $\mathrm{LIC}<3 \mathrm{mg} \mathrm{Fe} / \mathrm{g} \mathrm{dw}$ and the change in serum ferritin. LIC was measured at baseline then every 6 months using a validated R2 MRI technique (FerriScan ${ }^{\circledR}$; Resonance Health, Perth, Australia) [12].

Secondary endpoints included correlation of serum ferritin with LIC and change in LIC and serum ferritin in patients who interrupted therapy as a result of LIC $<3 \mathrm{mg} \mathrm{Fe} / \mathrm{g} \mathrm{dw}$ or serum ferritin $<100 \mathrm{ng} / \mathrm{mL}$.

Serum ferritin was measured at baseline then monthly or quarterly (depending on whether the patient was still receiving deferasirox). Mean iron excretion was calculated by adapting the Angelucci formula [13]: mean iron excretion $(\mathrm{mg} / \mathrm{kg} /$ day $)=10.6 \times($ change in LIC $) /$ days $(730)$.

Safety was evaluated through continuous monitoring and recording of AEs, laboratory testing, and clinical evaluations. For patients with LIC $<5 \mathrm{mg} \mathrm{Fe} / \mathrm{g} \mathrm{dw}$ or serum ferritin $\leq 300 \mathrm{ng} / \mathrm{mL}, \mathrm{AE}$ incidence before and after the first day of the event was summarized and adjusted for exposure duration.

\section{Statistical methods}

Statistical analyses for the core have been reported previously [9]. For the primary efficacy analysis, the proportion of patients who reached LIC $<5 \mathrm{mg} \mathrm{Fe} / \mathrm{g}$ dw by the end of the extension is presented with a $95 \%$ confidence interval (Wilson CI) [14]. For data analyses presented by average actual dose, patients were summarized by the dose category regardless of their treatment groups. Descriptive statistics were used to present efficacy analyses. Compliance was reported as planned dose taken= $100 \times$ cumulative dose taken/cumulative planned dose.

Data were assessed by various groupings (core + extension and extension only) and core randomization arms. Primary analysis set for efficacy is the core+extension full analysis set (FAS) consisting of randomized patients in the core. Analyses for the core+extension FAS summarized data cumulatively from core randomization date. The extension FAS is randomized patients who entered the extension.

The core+extension safety set consists of all randomized patients who received $\geq 1$ study drug dose. Analyses summarized all safety data cumulatively from the start date of the first dose in the core. Extension safety set was all randomized patients who entered the extension and received $\geq 1$ deferasirox dose during the extension.
When reporting events by starting dose in the extension only, if the first actual deferasirox dose in the extension was $<15 \mathrm{mg} / \mathrm{kg} / \mathrm{day}$, the patient was analyzed in the combined $\leq 10 \mathrm{mg} / \mathrm{kg} /$ day group; if the first actual dose in the extension was $\geq 15 \mathrm{mg} / \mathrm{kg} / \mathrm{day}$, the patient was analyzed in the $20 \mathrm{mg} / \mathrm{kg} /$ day group.

The study was sponsored by Novartis Pharma AG and designed by the sponsor in collaboration with the Study Steering Committee composed of expert hematologists in the thalassemia field. The sponsor conducted the statistical analysis. Authors had full access to data and actively participated in data interpretation and drafting/critical manuscript review, with the assistance of a medical writer funded by the sponsor. The corresponding author had final responsibility for manuscript content and decision to submit for publication.

\section{Results}

Patient disposition and baseline demographics

Overall, 148 patients completed the core (97 and 51 in the deferasirox and placebo arm, respectively) [9], of whom 15 did not enroll in the extension (Fig. 2). Of the 133 patients entering into the extension, 130 completed.

\section{Blood transfusions and exposure to treatment}

For patients receiving deferasirox in the core and extension $(n=110), 88(80.0 \%)$ did not receive blood transfusions during the study. Twelve (10.9\%), five (4.5\%), two $(1.8 \%)$, one $(0.9 \%)$, and two $(1.8 \%)$ patients received 1 , $2,3,4$, or $>4$ transfusions, respectively.

Patients receiving deferasirox in the core and extension were treated for a median duration of 23.3 months (range 0.2-27.1). In the extension year, the median duration of deferasirox was 11.1 months (range 1.1-12.2). Taking into consideration dose adjustments and the fact that patients entering the extension could begin at a $20 \mathrm{mg} / \mathrm{kg} /$ day starting dose whereas in the core starting doses were 5 or $10 \mathrm{mg} / \mathrm{kg} /$ day, the mean actual deferasirox dose in the deferasirox core+extension group was $9.8 \pm 3.6$ (median 9.5) $\mathrm{mg} / \mathrm{kg} /$ day. In the deferasirox extension group, the mean actual deferasirox dose was $12.6 \pm$ 4.5 (median 10.8) $\mathrm{mg} / \mathrm{kg} / \mathrm{day}$, and for patients in the crossover extension group it was higher at $13.7 \pm 4.6$ (median 14.0) $\mathrm{mg} / \mathrm{kg} /$ day (Table 1).

For patients entering the extension phase, in the deferasirox extension group, $64(78.0 \%)$ patients were in the $\leq 10 \mathrm{mg} / \mathrm{kg} /$ day group and $18(22.0 \%)$ patients were in the $20 \mathrm{mg} / \mathrm{kg} /$ day group. In the crossover group, 27 (56.3\%) were in the $\leq 10 \mathrm{mg} / \mathrm{kg} / \mathrm{day}$ and $21(43.8 \%)$ were in the $20 \mathrm{mg} / \mathrm{kg} /$ day groups. 


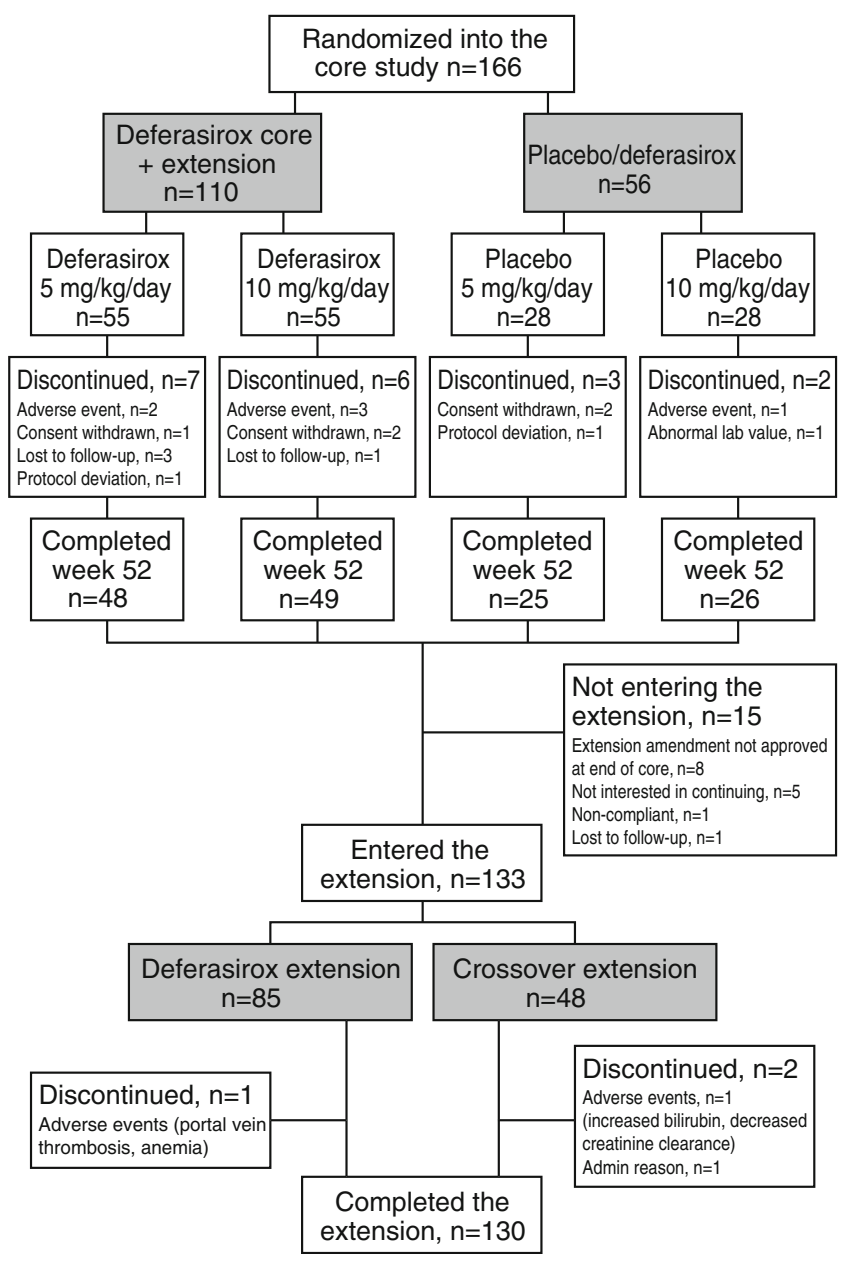

Fig. 2 Patient disposition (groups reported in manuscript shaded in gray)

Average actual dose by dose category is shown in Table 1 . In the deferasirox extension group, average actual dose breakdown was similar to those who were switching from placebo to deferasirox. Medication compliance was high in the extension phase with $97.2 \pm 7.0 \%$ in the deferasirox extension group and $96.0 \pm 8.1 \%$ in the crossover extension group taking the planned dose.

In the extension phase, doses were decreased as a result of AEs in $19(23.2 \%)$ patients in the deferasirox extension group [main reason gastroenteritis (six patients)] and 18
(37.5\%) patients in the crossover extension group [main reason gastroenteritis (four patients)].

\section{Effect of deferasirox on LIC and serum ferritin}

Following the LIC decrease over 1 year with deferasirox, mean LIC continued to decrease over another year (Fig. 3). Baseline LIC $[ \pm$ standard deviation (SD)] in the deferasirox core+extension group $(n=110)$ was $13.84 \pm 7.61 \mathrm{mg} \mathrm{Fe} / \mathrm{g} \mathrm{dw}$; at month 24, LIC had decreased to $7.51 \pm 6.21 \mathrm{mg} \mathrm{Fe} / \mathrm{g} \mathrm{dw}$ (mean absolute change $-7.14 \pm 5.3 \mathrm{mg} \mathrm{Fe} / \mathrm{g} \mathrm{dw}$ ). For the placebo/deferasirox group $(n=56)$, baseline LIC was $15.94 \pm$ $10.85 \mathrm{mg} \mathrm{Fe} / \mathrm{g} \mathrm{dw}$; at 1 year with placebo, mean LIC increased to $16.38 \pm 10.43 \mathrm{mg} \mathrm{Fe} / \mathrm{g} \mathrm{dw}$. Following the crossover to deferasirox in the extension phase, mean LIC decreased to $10.28 \pm 8.80 \mathrm{mg} \mathrm{Fe} / \mathrm{g} \mathrm{dw}$ at month 24 (mean absolute change baseline to month $24=-6.66 \pm 6.63 \mathrm{mg} \mathrm{Fe} / \mathrm{g} \mathrm{dw}$ ).

In the deferasirox core + extension group, absolute change in LIC by average actual dose category showed a dose response, with the highest decreases seen in the higher dose groups. Mean \pm SD change in LIC from baseline to month 24 was $-4.4 \pm 4.60,-6.6 \pm 3.99,-10.0 \pm 5.86$, and $-10.4 \pm 11.53$ in the $>0$ to $<7.5(n=15), 7.5-12.5(n=47),>12.5-17.5(n=$ $18)$, and $>17.5(n=4) \mathrm{mg} / \mathrm{kg} /$ day groups, respectively.

At 24 months, the largest absolute decrease in LIC was seen in patients with the higher baseline LIC. Patients in the deferasirox core+extension group with a baseline LIC of $\leq 7 \quad(n=18)$, $>7-15(n=57)$, and $>15 \mathrm{mg} \mathrm{Fe} / \mathrm{g} \mathrm{dw}(n=35)$ had a mean \pm SD LIC reduction of $-2.5 \pm 1.16(n=10),-5.4 \pm 2.66(n=45)$, and $-11.4 \pm 6.31 \mathrm{mg} \mathrm{Fe} / \mathrm{g} \mathrm{dw}(n=29)$, respectively. The overall mean net iron excretion was $0.104 \mathrm{mg} / \mathrm{kg} /$ day; in patients with baseline LIC $\leq 7,7-15$, and $>15 \mathrm{mg} \mathrm{Fe} / \mathrm{g} \mathrm{dw}$, the mean iron excretion was $0.036,0.078$, and $0.166 \mathrm{mg} / \mathrm{kg} /$ day, respectively.

The percentage of patients achieving LIC $<5$ and $<3 \mathrm{mg}$ $\mathrm{Fe} / \mathrm{g} \mathrm{dw}$ continued to increase over 2 years. Of 166 patients enrolled, 29 (17.5\%) patients achieved LIC $<5 \mathrm{mg} \mathrm{Fe} / \mathrm{g} \mathrm{dw}$ by the end of the core [15 (9.0\%) patients in the deferasirox $10 \mathrm{mg} / \mathrm{kg} /$ day group, nine $(5.4 \%)$ in the deferasirox $5 \mathrm{mg} / \mathrm{kg}$ /day group, and five (3.0\%) in the placebo group (apparent improvement in the placebo group attributable to MRI variability)] [9, 12]. By the end of the extension, the number of patients who had achieved LIC $<5 \mathrm{mg} \mathrm{Fe} / \mathrm{g} \mathrm{dw}$
Table 1 Average actual dose and dose categories

\begin{tabular}{|c|c|c|c|c|c|c|}
\hline \multirow[t]{2}{*}{ Group } & \multirow{2}{*}{$\begin{array}{l}\text { Mean } \pm \text { SD actual } \\
\text { dose }(\mathrm{mg} / \mathrm{kg} / \text { day })\end{array}$} & \multirow{2}{*}{$\begin{array}{l}\text { Median actual } \\
\text { dose }(\mathrm{mg} / \mathrm{kg} / \text { day })\end{array}$} & \multicolumn{4}{|c|}{ Dose categories (mg/kg/day), $n(\%)$} \\
\hline & & & $>0-\leq 7.5$ & $7.5-12.5$ & $>12.5-17.5$ & $>17.5$ \\
\hline $\begin{array}{l}\text { Deferasirox core }+ \\
\quad \text { extension }(n=110)\end{array}$ & $9.8 \pm 3.6$ & 9.5 & $32(29.1)$ & $53(48.2)$ & $21(19.1)$ & $4(3.6)$ \\
\hline $\begin{array}{l}\text { Deferasirox extension } \\
\quad(n=82)\end{array}$ & $12.6 \pm 4.5$ & 10.8 & $6(7.3)$ & $40(48.8)$ & $19(23.2)$ & $17(20.7)$ \\
\hline $\begin{array}{l}\text { Crossover extension } \\
\quad(n=48)\end{array}$ & $13.7 \pm 4.6$ & 14.0 & $2(4.2)$ & $21(43.8)$ & $11(22.9)$ & $14(29.2)$ \\
\hline
\end{tabular}




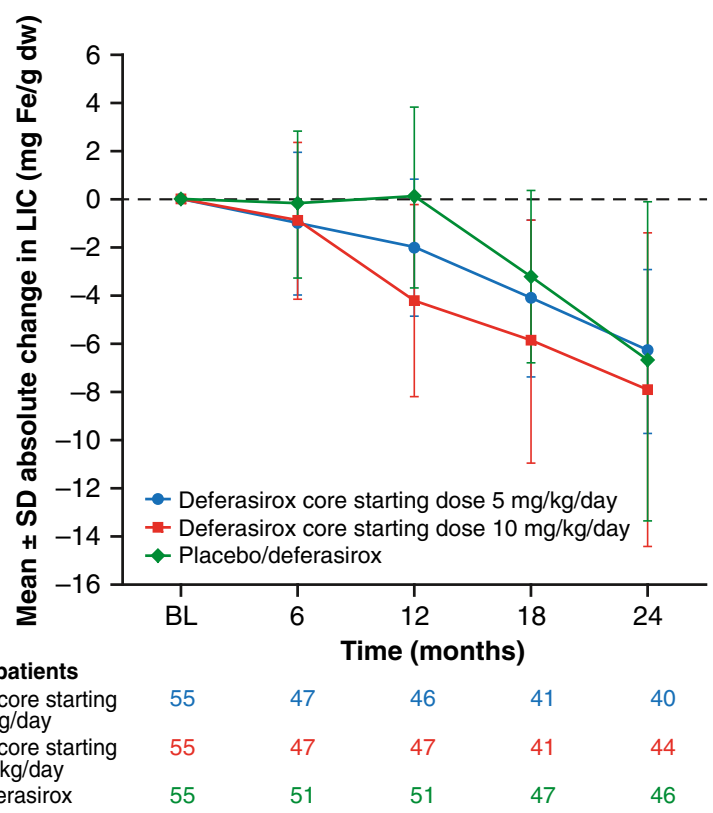

Fig. 3 Absolute change \pm SD in LIC with deferasirox treatment up to 2 years

had increased to 64 [38.6\%; 43/110 (39.1\%; $95 \%$ CI 30.5, 48.4) patients in the deferasirox core+extension group and $21 / 56(37.5 \%$; $95 \%$ CI 26.0, 50.6) patients in the placebo/ deferasirox group]. Overall, six (3.6\%) patients achieved LIC $<3 \mathrm{mg} \mathrm{Fe} / \mathrm{g} \mathrm{dw}$ by the end of the core study; this increased to $24(14.5 \%)$ by the end of the extension.

Twenty-four patients in the core+extension who stopped deferasirox as a result of achieving LIC $<3 \mathrm{mg} \mathrm{Fe} / \mathrm{g}$ dw or serum ferritin $<100 \mathrm{ng} / \mathrm{mL}$ had a mean LIC at the time of stopping of $2.20 \pm 0.49 \mathrm{mg} \mathrm{Fe} / \mathrm{g} \mathrm{dw}$. These patients were followed up over an average duration of 257.8 days (range 162-362), and the last available LIC was $3.08 \pm 1.74 \mathrm{mg} \mathrm{Fe} / \mathrm{g}$ $\mathrm{dw}(n=13)$, with an absolute change after stopping of $+0.87 \pm$ 1.36 (range $-1.4-4.5$ ).

It is important to note that patients receiving placebo in the core and then deferasirox in the extension entered the extension with a higher extension baseline LIC (16.3 vs. $11.0 \mathrm{mg} \mathrm{Fe} / \mathrm{g} \mathrm{dw}$ ) and received a higher average actual deferasirox dose than those continuing on deferasirox (Table 1). In the extension phase, patients with higher extension baseline LIC and in the higher dose categories achieved the greatest reduction in LIC (Fig. 4).

Following the serum ferritin decrease over 1 year with deferasirox (median decrease $-163.3 \mathrm{ng} / \mathrm{mL}$ ), serum ferritin continued to decrease over another year (median decrease $-472.0 \mathrm{ng} / \mathrm{mL}$ from baseline to month 24 ) in the deferasirox core and extension group (Fig. 5). Serum ferritin also decreased in the group switching from placebo to deferasirox in the extension (median decrease $-310.8 \mathrm{ng} / \mathrm{mL}$ from baseline to month 24). For patients with extension baseline serum a
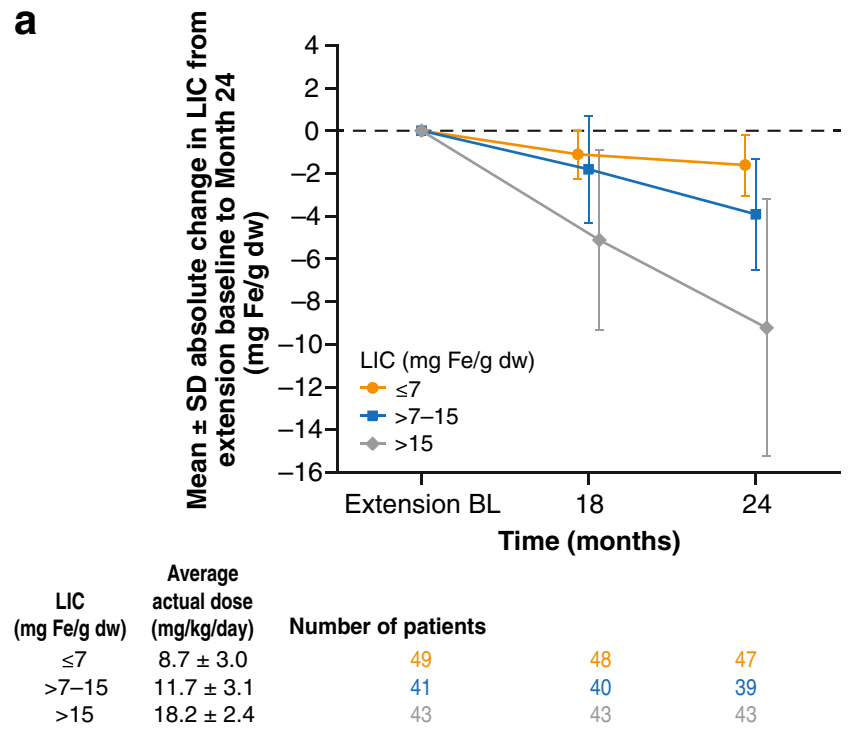

b

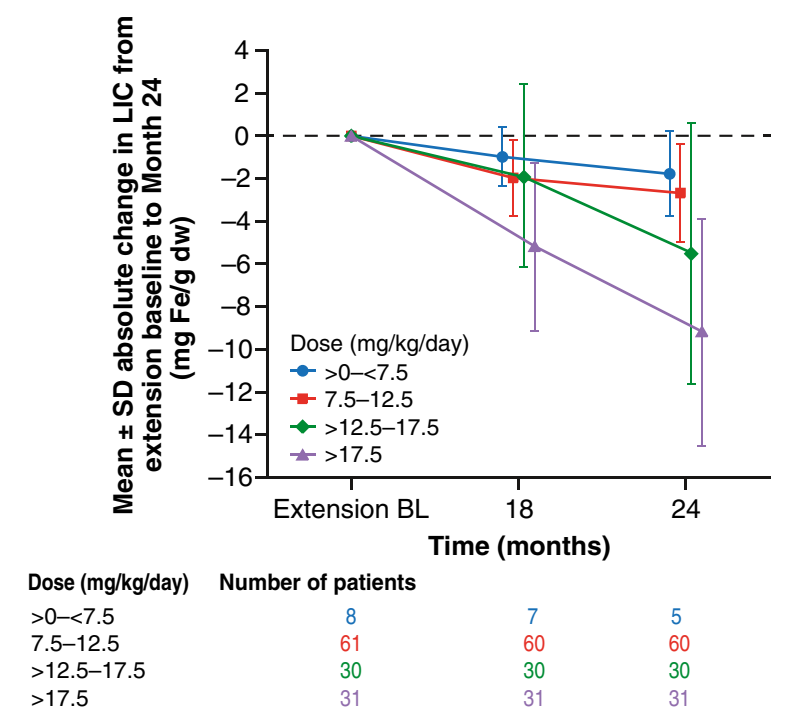

Fig. 4 a Mean \pm SD absolute change in LIC by extension baseline LIC categories from extension baseline to month 24. b Mean \pm SD absolute change in LIC by average actual dose categories from extension baseline to month 24 (all patients $n=133$ )

ferritin $>300 \mathrm{ng} / \mathrm{mL}(n=128), 18(14.1 \%)$ achieved serum ferritin $<300 \mathrm{ng} / \mathrm{mL}$ at the end of the extension.

Safety profile and laboratory parameters

Overall, the safety profile of deferasirox up to 2 years was consistent with that seen in the core study [9]. Over the 2 years, investigator-assessed drug-related AEs were reported in 35 (31.8 \%) patients; most common ( $>5 \%$ ) were diarrhea, nausea, and rash [all seven (6.4\%)].

For patients treated with deferasirox for up to 2 years, the number of patients with worsening or new AEs, regardless of 


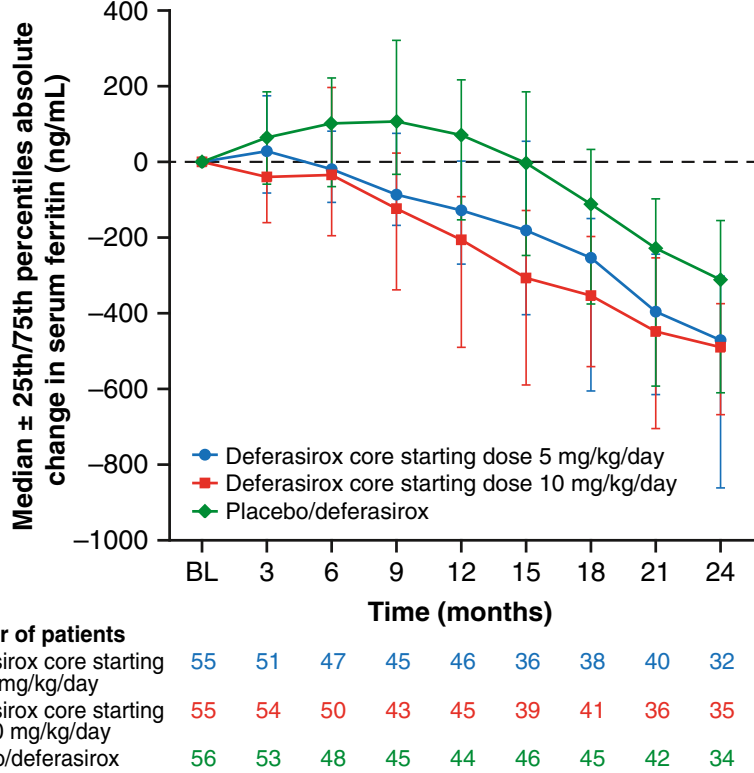

Fig. 5 Median absolute change ( \pm 25 th/75th percentiles) in serum ferritin over time with deferasirox treatment for up to 2 years study drug relationship, before and after the first measurement of LIC $<5 \mathrm{mg} \mathrm{Fe} / \mathrm{g}$ dw or serum ferritin $\leq 300 \mathrm{ng} / \mathrm{mL} \quad(n=43)$ was $36(83.7 \%$; exposure-adjusted $36 / 45.2$ years $=0.80 /$ year $)$ and 24 (55.8\%; exposure-adjusted $24 / 28.8$ years $=0.83 /$ year $)$, respectively.

Over the 2 years of treatment, there was a decreasing trend in mean ALT (Fig. 6). Mean serum creatinine and creatinine clearance measurements showed slight increasing and decreasing trends, respectively; urinary protein/creatinine ratio after an initial increase remained stable over 2 years (Fig. 6)

In the extension phase, AEs regardless of study drug relationship were reported in $69.5 \%$ of patients in the deferasirox extension group $(68.8 \%$ and $72.2 \%$ in the $\leq 10$ and $20 \mathrm{mg} / \mathrm{kg} /$ day groups, respectively) and $81.3 \%$ in the crossover group ( $85.2 \%$ and $76.2 \%$ in the $\leq 10$ and $20 \mathrm{mg} / \mathrm{kg} / \mathrm{day}$ groups, respectively). The most common AEs (>10\%) regardless of study drug relationship in all patients were upper respiratory tract infection $(17.7 \%)$, diarrhea (14.6\%), pyrexia $(12.3 \%)$, and upper abdominal pain $(11.5 \%)$.

In the extension phase, investigator-assessed deferasiroxrelated AEs were reported in $14(17.1 \%)$ and $13(27.1 \%)$
Fig. 6 Mean ALT, serum creatinine, creatinine clearance, and urinary protein/creatinine ratio over 2 years.

Measurements in month 24 were defined as those with study day greater than $30 \times 24-15=$ 705. In all safety analyses, the observations or measurements after 28 days of the last treatment would be excluded a

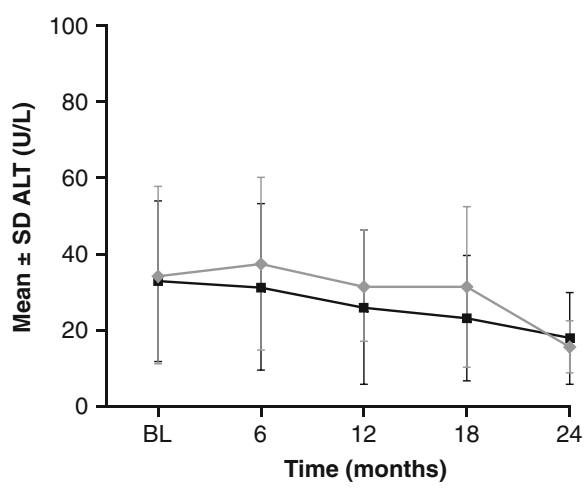

Number of patients Deferasirox Placebo/deferasi

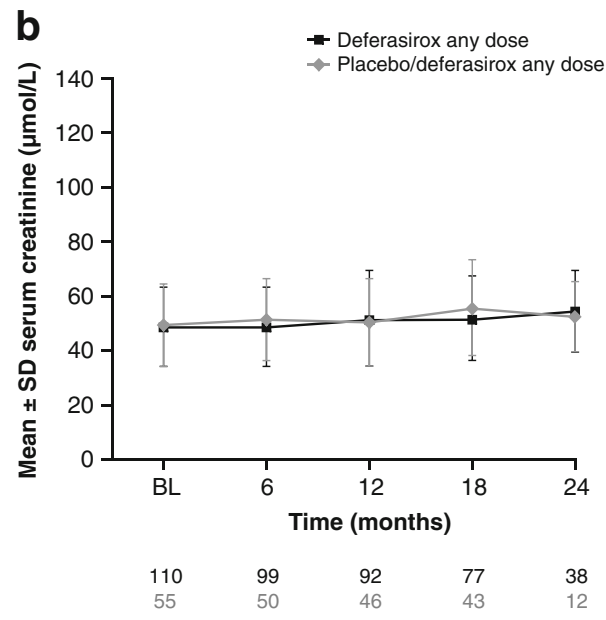

Number of patients Deferasirox Placebo/deferasirox
C
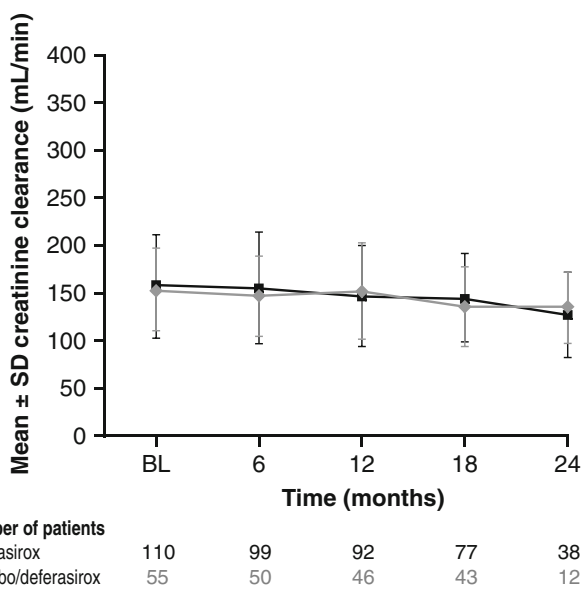

$\begin{array}{lllll}110 & 99 & 92 & 77 & 38\end{array}$

d

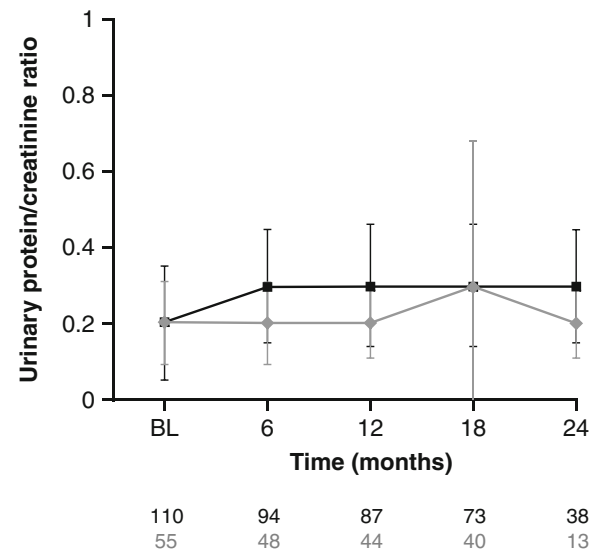


Table 2 Investigator-assessed drug-related AEs ( $\geq 3$ overall) by starting dose in the extension

\begin{tabular}{lllll}
\hline AE & \multicolumn{2}{l}{ Deferasirox (extension study) } & \multicolumn{2}{l}{ Crossover (extension study) } \\
\cline { 2 - 3 } & $\leq 10 \mathrm{mg} / \mathrm{kg} /$ day $(n=64) n(\%)$ & $20 \mathrm{mg} / \mathrm{kg} /$ day $(n=18) n(\%)$ & $\leq 10 \mathrm{mg} / \mathrm{kg} / \mathrm{day}(n=27) n(\%)$ & $20 \mathrm{mg} / \mathrm{kg} / \mathrm{day}(n=21) n(\%)$ \\
\hline Diarrhea & $2(3.1)$ & $1(5.6)$ & $3(11.1)$ & $1(4.8)$ \\
Upper abdominal pain & $2(3.1)$ & $0(0.0)$ & $2(7.4)$ & $0(0.0)$ \\
$\begin{array}{l}\text { Increased blood } \\
\quad \text { creatinine }\end{array}$ & $2(3.1)$ & $1(5.6)$ & $1(3.7)$ & $1(4.8)$ \\
Headache & $3(4.7)$ & $0(0.0)$ & $1(3.7)$ & $0(0.0)$ \\
Nausea & $1(1.6)$ & $0(0.0)$ & $1(3.7)$ & $0(0.0)$ \\
Abdominal pain & $2(3.1)$ & $0(0.0)$ & $1(3.7)$ & $0(0.0)$ \\
Skin rash & $0(0.0)$ & $0(0.0)$ & $1(3.7)$ & $1(4.8)$
\end{tabular}

patients in the deferasirox extension and crossover extension groups, respectively. The most common ( $\geq 3$ patients) were diarrhea, blood creatinine increase, and headache [all three patients $(3.7 \%)$ in the deferasirox extension group; diarrhea, four patients $(8.3 \%)$ in the crossover group; Table 2]. Serious AEs (SAEs) regardless of study drug relationship were observed in $10(12.2 \%)$ patients in the deferasirox extension group [most common gastroenteritis, five patients $(6.1 \%)$ ] and $10(20.8 \%)$ patients in the crossover extension group [most common anemia, three patients $(6.3 \%)$ ]. One SAE (hepatitis) suspected to be drug-related was observed in the crossover $20 \mathrm{mg} / \mathrm{kg} /$ day group, which lasted for 47 days (grade-severity three). Deferasirox dose was temporarily interrupted and the patient was hospitalized. The SAE resolved and the patient was restarted on $5 \mathrm{mg} / \mathrm{kg} /$ day and completed the extension phase. No deaths occurred in the study.

In the extension phase, one patient in the deferasirox $\leq 10 \mathrm{mg} / \mathrm{kg} /$ day extension group and one patient in the crossover $20 \mathrm{mg} / \mathrm{kg} /$ day extension group had an increase in ALT $>5 \times$ ULN and $>2 \times$ baseline on two consecutive visits (absolute values - 106, 114 and 400, $298 \mathrm{U} / \mathrm{L}$, respectively); both had abnormal extension baseline ALT ( $>$ ULN to $\leq 5 \times$ ULN). The crossover patient also had one aspartate aminotransferase $($ AST) value $>5 \times$ ULN and $>2 \times$ baseline $($ AST $\leq U L N$ at baseline). Deferasirox was interrupted and then restarted in both patients; the ALT and AST increases observed were transient. One additional patient experienced one AST value $>5 \times$ ULN and $>2 \times$ baseline in the deferasirox $\leq 10 \mathrm{mg} / \mathrm{kg} / \mathrm{day}$ extension group (AST $\leq \mathrm{ULN}$ at extension baseline). AST levels returned to normal without dose amendment or interruption. Elevated transaminases were also reported as AEs in the above patients.

Two patients (one patient in the deferasirox extension group and one in the crossover group) had serum creatinine increases $>33 \%$ above baseline and above ULN $(106 \mu \mathrm{mol} / \mathrm{L})$ on $\geq 2$ consecutive visits while taking $20 \mathrm{mg} / \mathrm{kg} /$ day deferasirox (absolute values-120 and $114 \mu \mathrm{mol} / \mathrm{L}$ in the deferasirox extension patient and $112-142 \mu \mathrm{mol} / \mathrm{L}$ in the crossover patient). Both patients had normal serum creatinine at extension baseline. The deferasirox dose in the deferasirox extension group patient was reduced and the serum creatinine levels normalized. Elevated creatinine was also reported as an AE in this patient. In the patient in the crossover group, serum creatinine started improving after drug interruption (last value remained $114 \mu \mathrm{mol} / \mathrm{L}$ ). This patient also developed creatinine clearance $<60 \mathrm{~mL} / \mathrm{min}$ at $\geq 2$ consecutive visits. Creatinine clearance before crossing over to deferasirox was $69 \mathrm{~mL} / \mathrm{min}$ and then it fluctuated from 40 to $58 \mathrm{~mL} / \mathrm{min}$.

One patient in the deferasirox extension group had creatinine clearance $<60 \mathrm{~mL} / \mathrm{min}$ at $\geq 2$ consecutive visits (absolute values ranged from 54 to $59 \mathrm{~mL} / \mathrm{min}$ ) while taking $5 \mathrm{mg} / \mathrm{kg} /$ day. This patient had an extension baseline creatinine clearance $<60 \mathrm{~mL} / \mathrm{min}$. The dose was not changed; at the next assessments, creatinine clearance ranged from 52 to $60 \mathrm{~mL} / \mathrm{min}$.

One patient in the crossover extension group had urinary protein/creatinine ratio $>1.0 \mathrm{mg} / \mathrm{mg}$ at $\geq 2$ consecutive values (absolute values ranged from 2.41 to 4.01) while taking $20 \mathrm{mg} / \mathrm{kg} /$ day. This patient had an abnormal urinary protein/ creatinine ratio of $>0.2$ to $\leq 1 \mathrm{mg} / \mathrm{mg}$ at both core and extension baseline. After drug interruption and deferasirox reinstatement at $20 \mathrm{mg} / \mathrm{kg} /$ day, urinary protein/creatinine ratio returned to baseline values at the end of the extension.

Mean \pm SD hemoglobin levels remained stable during the extension phase (all patients: extension baseline-78.2 \pm $16.5 \mathrm{~g} / \mathrm{L}$, month $24-79.8 \pm 16.7 \mathrm{~g} / \mathrm{L})$.

\section{Discussion}

The THALASSA trial provides the largest dataset for iron chelation in NTDT to date, confirming preliminary findings of iron reduction in small studies/case reports [3-8, 10, 11, 15]. The 1-year study established a treatment paradigm for iron-overloaded NTDT patients whereby chelation with deferasirox can be initiated when LIC exceeds $5 \mathrm{mg} \mathrm{Fe} / \mathrm{g}$ 
$\mathrm{dw}$ and continued with a treatment goal of reducing LIC below a threshold associated with complications [2].

Following the randomized, placebo-controlled 1-year trial, we report here results from a 1-year extension phase, providing the longest assessment duration of any iron chelator in NTDT patients in a controlled trial setting. From the baseline LIC and serum ferritin reported [9], it is clear that despite no/limited transfusions, these patients have high iron burden, and this high burden has been associated with complications such as bone disease, thromboembolism, endocrinopathy, pulmonary hypertension, cerebrovascular and neuronal damage, liver fibrosis or cirrhosis, and increased risk of hepatocellular carcinoma (for overview see [16]).

Patients receiving deferasirox for one additional year after the core study continued to respond with a decrease in LIC and serum ferritin over 2 years. Overall, for patients receiving deferasirox for up to 2 years, approximately $40 \%$ and $16 \%$ reached LIC $<5$ and $<3 \mathrm{mg} \mathrm{Fe} / \mathrm{g} \mathrm{dw}$, respectively, with more patients reaching these targets during the second year, indicating that with appropriate dosing and continued treatment deferasirox continues to effectively remove iron.

Patients crossing over from placebo in the core to deferasirox in the extension also showed a considerable decrease in LIC and serum ferritin. These patients entered the extension with a higher extension baseline LIC, and received a higher actual average deferasirox dose during the extension, than those who received deferasirox during the core and continued with treatment in the extension. This has contributed to the large decrease in LIC seen in the crossover patients. This highlights the importance of monitoring iron burden and dose adjusting when necessary to achieve therapeutic goals.

The safety profile over 2 years of deferasirox treatment did not differ from that observed in the core 1-year study. The overall incidence of AEs and abnormal laboratory parameters were comparable in the extension and core phase [9]. The safety profile did not appear to differ in the $\leq 10$ and the $20 \mathrm{mg} / \mathrm{kg} /$ day dose groups in the extension phase. There was a gradual decrease in mean ALT over time, potentially indicating a decrease in iron-related hepatocellular injury. A slight increase in serum creatinine, gradual over 2 years, was observed as the average dose increased.

The number of patients with worsening or new AEs, regardless of drug relationship, whose LIC was $<5 \mathrm{mg} \mathrm{Fe} / \mathrm{g}$ $\mathrm{dw}$ or serum ferritin was $\leq 300 \mathrm{ng} / \mathrm{mL}$ did not appear to differ overall from that prior to achieving these levels, indicating that chelation to these levels may not adversely affect the number of worsening or new AEs.

A recent study revealed that patients with LIC $>7$ and $>6 \mathrm{mg} \mathrm{Fe} / \mathrm{g} \mathrm{dw}$, respectively, were more likely to have an already established vascular or endocrine/bone morbidity [2]. Such information confirms the need to establish therapeutic LIC goals specific to NTDT, which are likely to differ from those already established in transfusiondependent patients. New NTDT guidelines [18], information on the link between LIC and comorbidities [2] as well as data from large studies on chelation such as THALASSA allow some recommendations to be considered. Data from THALASSA suggest that deferasirox can be used to reduce iron burden in patients with $\mathrm{LIC}>5 \mathrm{mg} \mathrm{Fe} / \mathrm{g}$ dw. Patients achieving LIC $<3 \mathrm{mg} \mathrm{Fe} / \mathrm{g} \mathrm{dw}$ may be able to interrupt chelation therapy; it is important to reiterate that LIC assessment is the preferred option in NTDT patients, although serum ferritin can be used to guide initiation, monitoring, and interruption of chelation therapy [17]. After patients reach the therapeutic target, the recommendation is to monitor them with LIC evaluation every 1-2 years if feasible, which will identify any patients whose LIC is approaching values of $>5 \mathrm{mg} \mathrm{Fe} / \mathrm{g}$ $\mathrm{dw}$ and hence would require reintroduction of iron chelation [18].

THALASSA is the longest controlled trial of iron chelation in NTDT; however, it will be of interest to observe patients over the longer term. In particular, it will be of interest to observe patients who interrupt their chelation because they achieved their therapeutic goals and to then determine when they need to be reintroduced to chelation therapy as their burden increases as they age.

In conclusion, THALASSA data confirm that deferasirox, with appropriate dosing, effectively reduces iron overload over 2 years with a manageable safety profile providing robust evidence to assist clinicians in managing iron overload in patients with NTDT.

Acknowledgments This study was funded by Novartis Pharma AG. We thank Michelle Utton-Mishra, $\mathrm{PhD}$, for medical editorial assistance. Financial support for medical editorial assistance was provided by Novartis Pharmaceuticals. For a full list of participating investigators and their affiliations please see electronic supplemental material.

Conflicts of interest ATT reports receiving research funding and honoraria from Novartis Pharmaceuticals; JBP reports received research funding from Novartis Pharmaceuticals, being a member of an advisory committee and participating in a Novartis speaker's bureau; VV received research grant support and lecture fees from Novartis Pharmaceuticals and research grant support from GPO L ONE, Thailand, FerroKin Biosciences, and National Research University (NRU), Thailand; AK reports received honoraria and research funding from Novartis Pharmaceuticals and participating in a speaker's bureau; SC, PS, and NS received research funding from Novartis Pharmaceuticals; RG received research grants and speaker's honoraria from Novartis Pharmaceuticals; ZK received research grants and speaker's honoraria from Novartis Pharmaceuticals; TL, JR, ZZ, and DH are full-time employees of Novartis Pharmaceuticals; MDC reports participating in a Novartis Pharmaceuticals speaker's bureau.

Open Access This article is distributed under the terms of the Creative Commons Attribution License which permits any use, distribution, and reproduction in any medium, provided the original author(s) and the source are credited. 


\section{References}

1. Taher AT, Musallam KM, El-Beshlawy A, Karimi M, Daar S, Belhoul K, Saned MS, Graziadei G, Cappellini MD (2010) Agerelated complications in treatment-naive patients with thalassaemia intermedia. Br J Haematol 150:486-489

2. Musallam KM, Cappellini MD, Wood JC, Motta I, Graziadei G, Tamim H, Taher AT (2011) Elevated liver iron concentration is a marker of increased morbidity in patients with $\beta$-thalassemia intermedia. Haematologica 96:1605-1612

3. Akrawinthawong K, Chaowalit N, Chatuparisuth T, Siritanaratkul $\mathrm{N}$ (2011) Effectiveness of deferiprone in transfusion-independent beta-thalassemia/HbE patients. Hematology 16:113-122

4. Chan JC, Chim C-S, Ooi CG, Cheung B, Liang R, Chan T-K, Chan $\mathrm{V}$ (2006) Use of the oral chelator deferiprone in the treatment of iron overload in patients with $\mathrm{Hb} \mathrm{H}$ disease. $\mathrm{Br} \mathrm{J}$ Haematol 133:198-205

5. Cossu P, Toccafondi C, Vardeu F, Sanna G, Frau F, Lobrano R, Cornacchia G, Nucaro A, Bertolino F, Loi A, De Virgiliis S, Cao A (1981) Iron overload and desferrioxamine chelation therapy in beta-thalassemia intermedia. Eur J Pediatr 137:267-271

6. Ladis V, Berdousi H, Gotsis E, Kattamis A (2010) Deferasirox administration for the treatment of non-transfusional iron overload in patients with thalassaemia intermedia. Br J Haematol 151:504508

7. Olivieri NF, Koren G, Matsui D, Liu PP, Blendis L, Cameron R, McClelland RA, Templeton DM (1992) Reduction of tissue iron stores and normalization of serum ferritin during treatment with the oral iron chelator L1 in thalassemia intermedia. Blood 79:2741-2748

8. Pootrakul P, Sirankapracha P, Sankote J, Kachintorn U, Maungsub W, Sriphen K, Thakernpol K, Atisuk K, Fucharoen S, Chantraluksri U, Shalev O, Hoffbrand AV (2003) Clinical trial of deferiprone iron chelation therapy in beta-thalassaemia/haemoglobin E patients in Thailand. Br J Haematol 122:305-310

9. Taher AT, Porter J, Viprakasit V, Kattamis A, Chuncharunee S, Sutcharitchan P, Siritanakatkul N, Galanello R, Karakas Z, Lawniczek T, Ros J, Zhang Y et al (2012) Deferasirox significantly reduces iron overload in non-transfusion-dependent thalassemia: 1-year results from a prospective, randomized, double-blind, placebo-controlled study. Blood 120:970-977

10. Voskaridou E, Plata E, Douskou M, Papadakis M, Delaki EE, Christoulas D, Terpos E (2010) Treatment with deferasirox (Exjade) effectively decreases iron burden in patients with thalassaemia intermedia: results of a pilot study. Br J Haematol 148:332334

11. Voskaridou E, Plata E, Douskou M, Sioni A, Mpoutou E, Christoulas D, Dimopoulou M, Terpos E (2011) Deferasirox effectively decreases iron burden in patients with double heterozygous $\mathrm{HbS} /$ beta-thalassemia. Ann Hematol 90:11-15

12. St Pierre TG, Clark PR, Chua-anusorn W, Fleming AJ, Jeffrey GP, Olynyk JK, Pootrakul P, Robins E, Lindeman R (2005) Noninvasive measurement and imaging of liver iron concentrations using proton magnetic resonance. Blood 105:855-861

13. Angelucci E, Brittenham GM, McLaren CE, Ripalti M, Baronciani D, Giardini C, Galimberti M, Polchi P, Lucarelli G (2000) Hepatic iron concentration and total body iron stores in thalassemia major. N Engl J Med 343:327-331

14. Agresti A, Coull BA (1998) Approximate is better than "exact" for interval estimation of binomial proportions. Am Stat 52:119-126

15. Rombos Y, Tzanetea R, Konstantopoulos K, Simitzis S, Zervas C, Kyriaki P, Kavouklis M, Aessopos A, Sakellaropoulos N, Karagiorga M, Kalotychou V, Loukopoulos D (2000) Chelation therapy in patients with thalassemia using the orally active iron chelator deferiprone (L1). Haematologica 85:115-117

16. Musallam KM, Cappellini MD, Wood JC, Taher AT (2012) Iron overload in non-transfusion-dependent thalassemia: a clinical perspective. Blood Rev 26(Suppl 1):S16-S19

17. Taher AT, Porter JB, Viprakasit V, Kattamis A, Chuncharunee S, Sutcharitchan P, Siritanakatkul N, Galanello R, Karakas Z, Lawniczek T, Habr D, Ros J et al. (2012) Estimation of liver iron concentration by serum ferritin measurement in non-transfusion-dependent thalassemia patients: analysis from the 1-year THALASSA study. Haematologica 97 (Suppl 1):abst 0927

18. Thalassaemia International Federation. Guidelines for the management of non transfusion dependent thalassaemia (NTDT). 2013. Available at: http://www.thalassaemia.org.cy/wordpress/wp-content/uploads/2013/05/NTDT-BOOKLET-FINAL-PDF.pdf. 